\title{
Antonio Candido e a Faculdade de Diretio
}

\section{Celso Lafer}

Universidade de São Paulo

Resumo

O artigo discute o papel da Faculdade de Direito no percurso de Antonio Candido, seja na formação da sua experiência de cidadania, seja na sua obra de crítico literário interessado nos temas e obras do Romantismo brasileiro que emanaram das Arcadas. Trata de como equacionou a relação entre Direito e Literatura por meio da formulação de um direito à literatura.

Abstract

The article examines the role of the Law School in the life and work of Antonio Candido. discusses what the Law School represented in his experience of citizenship and singles out the relevance for his activities as a literary critic of facets of Brazilian Romantism that emanated from the Law School. articulates how his formulation of the "right to literature" links Literature and Law.

\author{
Palavras-chave \\ Antonio \\ Candido; \\ Faculdade \\ de Direito; \\ Experiência \\ de cidadania; \\ Romantismo \\ Brasileiro; \\ Direito à \\ literatura
}

\section{Keywords}
Antonio
Candido;
Faculdade
de Direito;
Experience of
citizenship;
Brazilian
Romantism;
Right to
literature 


\section{A}

ntonio Candido é um grande intelectual, um professor extraordinário e uma figura humana exemplar. A sua obra - que abre caminhos para o entendimento do Brasil, da sua literatura e da criação artística, e a sua rica personalidade, que reúne tantas virtudes - oferecem ao estudioso mais de um ângulo para explicar as razões da sua autoridade intelectual. Esta é a de um grande Mestre que, no correr dos anos, tornou-se um ponto de referência da cultura brasileira. Daí a multiplicidade dos estudos dedicados ao seu percurso e as homenagens intelectuais que vem recebendo por ocasião dos seus 90 anos. Estas foram antecedidas, num adensamento crescente, pelas que celebraram os seus 60,70 e 80 anos, e que assinalam, no pluralismo das perspectivas discutidas, a força da sua presença na vida cultural do nosso país. Esta presença é de natureza geral, mas tem uma dimensão própria para os que foram seus alunos, tiveram o privilégio de assistir às suas aulas e beneficiaram-se do paciencioso empenho com o qual sempre cuidou da formação dos que com ele estudaram. É o meu caso, como posso dar meu afetuoso e reconhecido testemunho desde o tempo em que fui seu aluno no curso de 1961, de graduação, sobre Teoria e Análise do Romance dado na Faculdade de Filosofia, Ciências e Letras da USP na disciplina por ele criada e regida de Teoria Literária e Literatura Comparada. A disciplina levou à institucionalização da área na USP. Está na origem do atual Departamento de Teoria Literária e Literatura Comparada da FFLCH e da sua revista Literatura e Sociedade. Este número da Revista para a qual tenho a satisfação de colaborar, está voltado para estudos e depoimentos sobre a obra e a personalidade intelectual de quem foi, na USP, o inspirador e catalisador deste campo de estudos. Um campo, como ele diz num ensaio sobre Literatura 
Comparada inserido em Recortes, que tem o seu papel próprio num país como o Brasil, "caracterizado pelo cruzamento intenso das culturas".

Para explicar o significado pessoal desta minha colaboração, permito-me lembrar o que disse na nota introdutória de agosto de 1962 do meu O judeu em Gil Vicente. Este livro, que Antonio Candido prefaciou com generosidade, foi elaborado no período em que fui seu aluno e na nota qualifiquei-o como "o querido mestre e amigo que, pelo exemplo de sua obra e com o encanto da sua figura humana, tem sido o nosso guia a quem este trabalho e a nossa própria formação intelectual tanto devem". Passados tantos anos, reitero esta afirmação de jovem com gratidão, virtude que, como observa Comte-Sponville com inspiração spinozeana, expressa o sentimento que acompanha a ideia da sua causa, que é, no caso, a generosidade de um grande Mestre e Amigo.

A aspiração de compartilhar o alcance da reflexão de Antonio Candido me levou, no correr dos anos, em mais de uma ocasião, a escrever sobre a sua obra. Faço uma sucinta remissão a alguns destes estudos, necessária para explicar a escolha do tema desta colaboração: Antonio Candido e a Faculdade de Direito.

\section{II}

Em Esboço de figura, livro que organizei para comemorar os seus 60 anos, procurei mostrar que uma das chaves para o entendimento do seu percurso é a fecundidade de uma inquietação recorrente, que se traduz na reflexão sobre a dialética da ordem e da desordem, do "a favor" e "do contra". Este oximoro, como todo oximoro bem sucedido, combina opostos que parecem excluir-se mutuamente. No contexto da obra de Antonio Candido reforçam a argúcia da sua análise, a ela conferindo uma profundidade própria, atenta à complexidade das incoerências e contradições. Propiciam o alcance de seus juízos reflexivos que, ao modo kantiano, extraem, na paixão pelo concreto da especificidade das obras o seu alcance geral. Elaborados com a qualidade de uma escrita singular, conferem à sua crítica literária a rara dimensão da criação. É por isso que ele não é apenas O observador literário, como disse em nota de 1959, a este seu livro, mas um criador que, na sua crítica, como na perfeição de suas aulas, é capaz "de cercar de muitos lados as faces da vida refletidas na literatura".

No estudo que elaborei para Dentro do texto, dentro da vida, livro organizado por Maria Ângela D'Incao e Eloísa Faria Scarabôtolo que celebrou os seus 70 anos, examinei as suas posições políticas e a interação que comportam com a sua obra e visão das coisas e do mundo. No trato destas posições, representativas do grande tema dos desafios da participação do intelectual na política no século XX, procurei mostrar que se caracterizam por duas vertentes distintas, porém complementares: (a) a da resistência democrática à ordem do arbítrio nos períodos ditatoriais que viveu - o Estado Novo e o Regime Militar - e (b) o da afirmação de uma identidade socialista, animada pelos sentimentos de fraternidade igualitária e complementada pelo pensar e pelo agir, na vivência das nossas experiências democráticas. Na sequência da minha análise procurei 
mostrar como, na sua reflexão, a interação entre a política, visualizada como a ordem da igualdade, e a literatura, vivida como a aventura da liberdade criativa, ecoa de maneira própria o oximoro anteriormente apontado.

Nos 80 anos de Antonio Candido, a Folha de S. Paulo organizou um suplemento do Mais!, dedicado a celebrar o evento. Contribuí com um pequeno artigo no qual explorei, pela primeira vez, a relação entre Antonio Candido e a Faculdade de Direito de São Paulo. Retomo o tema neste texto, pois a Faculdade de Direito tem uma relação com a sua vida e a sua obra e esta relação tem pontos de contato com as análises empreendidas nos meus dois estudos acima sumariados.

\section{III}

Antonio Candido completou o curso secundário no Colégio Universitário, anexo à Universidade de São Paulo. Cursou, em 1937 e 1938, a sua primeira seção que funcionava na Faculdade de Direito e preparava os alunos para o ingresso no ensino universitário de Direito, Filosofia, Ciências Sociais, Geografia e História. Fez e passou, em 1939, dois exames vestibulares, o para a Faculdade de Filosofia e o para a Faculdade de Direito. Assistia, de manhã, às aulas de Direito e, à tarde, as da Faculdade de Filosofia. Formou-se em Ciências Sociais na Faculdade de Filosofia. Fez o curso de Direito até o quinto ano - com pouca assiduidade a partir do quarto ano, quando foi nomeado assistente de Fernando de Azevedo na Faculdade de Filosofia - não tendo feito o exame final de conclusão do curso, como narra na entrevista a Gilberto Velho e Yonne Leite publicada na Revista da SBPC, Ciência Hoje (vol. 16, n. 91, junho de 1993). Nesta mesma entrevista, diz que se considera oriundo de duas Faculdades e, realçando a importância fundamental da Faculdade de Filosofia na sua formação, registra também: "[...] tenho apego pela Faculdade de Direito, onde me iniciei na militância política”.

Qual é o significado deste apego? Diz Hume, em A treatise on human understanding (Parte IV, 6), que a memória não produz mas descobre a identidade pessoal, mostrando-nos a relação de causa e efeito entre as nossas diferentes percepções. Neste sentido, como procurarei mostrar, a memória de Antonio Candido sobre a sua passagem pelas Arcadas, debaixo das quais viveu sete anos, dois no pré-jurídico do Colégio Universitário e cinco no curso de bacharelado, contribui para explicar a especificidade da sua identidade.

Assim, no discurso que pronunciou em 30 de agosto de 1984 ao receber o título de professor emérito da Faculdade de Filosofia, Letras e Ciências Humanas, ao refletir sobre o seu percurso e sobre a importância da Faculdade de Filosofia na sua formação, na sua vida e no papel por ela desempenhado no ensino e na cultura do país, não deixou de registrar seu apego pela Faculdade de Direito. Diz neste discurso "O saber e o ato", publicado em Lingua e Literatura (ano X, vol. 10-13, 1981-1984): "Em 1939 fui admitido no curso superior em duas escolas: esta e a de Direito. Se a minha vocação estava aqui, na de Direito, 
recebi o ensino de alguns mestres exemplares, mergulhei durante anos numa das melhores bibliotecas de São Paulo e, sobretudo, recebi do ambiente o estímulo para definir uma consciência política. Nela me iniciei na atividade contra a ditadura daquele tempo - primeiro entre colegas liberais, depois entre colegas socialistas, reunidos para o mesmo combate. A Faculdade de Direito foi a minha grande escola de cidadania".

Recortes, que já mencionei ao tratar de Literatura Comparada na USP, é um livro de Antonio Candido que obedece, na sua composição, a uma lógica fragmentária. Esta lógica traduz, no seu pluralismo, o significado da obra, pessoas e instituições representativas do seu tempo afetivo e intelectual, como apontou Antonio Arnoni Prado na colaboração para o livro Antonio Candido - pensamento e militância, organizado por Flávio Aguiar e voltado para a celebração dos seus 80 anos. Para os propósitos da sua relação com a Faculdade de Direito, é significativo, em Recortes, o texto "Nas Arcadas". Nele Antonio Candido evoca suas lembranças da Faculdade de Direito com destaque para a "trepidação do inconformismo" dos estudantes em relação ao Estado Novo e à sempre presente atividade literária, e situa estas vertentes da sua experiência no contexto da histórica tradição da Faculdade de Direito na vida brasileira.

Sobre a constância do seu apego pela Faculdade de Direito, vale ainda a pena lembrar o discurso que pronunciou em 20 de agosto de 2008 ao receber o troféu do Prêmio Juca Pato de Intelectual do Ano. Nele apontou que uma das suas alegrias naquele momento era a de recebê-lo na Faculdade de Direito, na qual estudou e na qual começou "a militância contra as ditaduras", seja como um dos fundadores do Partido Libertador, que surgiu nas Arcadas como partido estudantil em 1939, seja subsequentemente como um dos fundadores da Frente de Resistência formada quando estava no quinto ano "por estudantes liberais e socialistas". Mencionou que "sempre me senti uma espécie de aluno permanente que ainda não cumpriu a sua tarefa, mas tenho a honra de ser bacharel do XI de Agosto, grau que me foi conferido solenemente por uma turma de formandos". Por isso trazia, naquele momento, "na lapela o distintivo do Centro, quase igual ao que em seguida ao trote de 1939, depois de raspado o cabelo e pagas as devidas taxas, recebi junto com a flâmula e o diploma de burro em bom latim macarrônico, diploma que conservo como antídoto salutar contra eventuais assomos de vaidade [...]".

Como se verifica, associado ao apego, a dimensão explícita da identidade de Antonio Candido, que tem a sua origem na Faculdade de Direito, é a da sua consciência política. Foi a experiência da ação conjunta de estudantes liberais e socialistas na luta contra o Estado Novo que teve o seu papel no modo da atuação política que assumiu na luta contra o regime militar instaurado em 1964. Como disse na entrevista dada a Heloísa Pontes, publicada na Revista Brasileira de Ciências Sociais (vol. 16, n. 47, outubro de 2001): "em tempos de fechamento as esquerdas e os liberais se unem; em tempos de abertura dá-se a decantação". 
Desta formulação vem a sua concepção, no período do regime militar, da relevância das Frentes Amplas que não são uma expressão "de oportunismo político", pois entende, como documentei na minha mencionada colaboração para o livro Dentro do texto, dentro da vida, que liberais autênticos e progressistas representam princípios e valores permanentes. Nas suas palavras, na entrevista a Jorge Cunha Lima, intitulada "Democracia e Socialismo", publicada na Isto É de 7/9/1977: "Pessoalmente sinto que o meu lado direito encosta com lealdade no seu lado esquerdo, formando um território comum, que permite a conversa e a ação também comuns".

Em 1977, no contexto da validade desta ação comum mais ampla reiterou, paradigmaticamente, como professor, sua experiência de estudante que, nas Arcadas, viveu a "trepidação do inconformismo". Voltou à Faculdade de Direito e assinou, como bacharel honorário, a Carta aos brasileiros elaborada por Goffredo Telles Jr. e lida no pátio da Faculdade em 8 de agosto de 1977, como um dos grandes eventos políticos que assinalaram o sesquicentenário da fundação dos cursos jurídicos no Brasil. A Carta reivindicava a restauração do Estado de Direito e contribuiu para a erosão do arbítrio do regime militar e para a posterior redemocratização do país nos anos 80. No entender de Antonio Candido, foi "um ato de bravura refletida", "simbolicamente legitimado por uma espécie de sanção popular" por conta das "manifestações de rua que ocorreram em seguida à leitura no centro da cidade" e que "despertou uma série de pronunciamentos em vários setores, equivalentes a uma onda de opinião democrática". No seu texto inserido no livro coletivo Estado de direito já! - Os trinta anos da Carta aos brasileiros, publicado em 2007, de onde extraí as referências acima, lembra que fez parte da "Comissão de professores que esperaram Goffredo da Silva Telles Junior no Largo de São Francisco e o introduziram no Pátio das Arcadas". Registra que tinha sido informado da elaboração do documento por José Carlos Dias e José Gregori e afirma: "A leitura foi eletrizante e um dos momentos mais altos de vibração cívica de que participei na vida".

$\mathrm{Na}$ decantação da sua identidade socialista em tempos de abertura que se traduziu no pós-Estado Novo, na sua participação no Partido Socialista Brasileiro e na época que se inicia com a erosão do regime militar, pela sua adesão ao PT, do qual foi fundador, também teve o seu papel numa dialética de complementaridade à memória política e afetiva do convívio acadêmico na Faculdade de Direito. Neste sentido, lembro a dedicatória a Teresina etc. O livro, que reúne ensaios que conjugam problemas culturais e políticos, contém o seu belo estudo sobre D. Teresina, a militante socialista italiana que viveu em Poços de Caldas, com a qual conviveu e que o influenciou. D. Teresina, diz ele, "ilustrava de maneira admirável o que é "ser socialista", tendo ele realçado, no seu perfil, "os sentimentos e a ética de um socialista". Teresina etc. é dedicado aos seus amigos e parceiros de atuação política que compartilhavam os valores do "ser socialista". Estão contemplados na dedicatória, Aziz Simão, 
Arnaldo Pedroso d'Horta, Febus Gikovate, Paulo Emílio Sales Gomes e seus companheiros de Esquerda, na Faculdade de Direito, Germinal Feijó e Antonio Correia Costa.

\section{IV}

A relação de Antonio Candido com a Faculdade de Direito não se circunscreve à dimensão política de sua identidade acima sumariada. Passava horas na biblioteca que evocou em "O Saber e o Ato", como relata numa entrevista dada em 1986 a Reflexo, o jornal dos alunos do $1^{\circ}$ ano da Faculdade (n. 3, outubro de 1986). "Gostava do ambiente sossegado, com o retrato de Álvares de Azevedo ali no canto". Foi lá que leu "os clássicos da crítica francesa, como Sainte-Beuve, Taine, Brunetière, Faguet", que foram relevantes, observo eu, na sua formação de crítico. Nesta entrevista dada a alunos do primeiro ano mencionou a importância que para ele teve o convívio acadêmico. O convívio acadêmico, além de ter propiciado "a escola de cidadania" teve também um papel na sua obra. Este papel está vinculado ao significado da Faculdade de Direito como um local de memória - ao modo indicado por Pierre Nora - da vida política, cultural e social do Brasil, para a qual foi decisivo o alcance do convívio acadêmico no correr de uma trajetória histórica que se iniciou com a sua criação em 1827.

O significado deste convívio para a vida brasileira foi examinado por A. Almeida Jr. - eminente educador, professor de Antonio Candido na Faculdade de Direito e de quem foi próximo - em estudo publicado na Revista da Faculdade de Direito (vol. XLVII, 1952). A este estudo Antonio Candido se refere em seu "A Literatura na evolução de uma comunidade", texto recolhido em Literatura e Sociedade. Aponta, com base em Almeida Jr., que a Faculdade, no século XIX, foi um meio plasmador de mentalidades e um ponto de encontro de quantos se interessavam pelas coisas do espírito e da vida pública que contribuiu para a formação da nacionalidade ao criar um vínculo de solidariedade entre aqueles que, na Academia do Largo de São Francisco, foram elaborando a sua visão de país, dos homens e do pensamento.

Em "Nas Arcadas" registra Antonio Candido que a Faculdade de Direito no seu tempo não era mais o único lugar aonde iam "os dirigentes de toda a vida do país, desde a economia até a literatura", mas havia ainda algo da força deste passado quando lá estudou. Isto incluía a atividade literária, e menciona a coletânea Poesia sob as Arcadas organizada por Ulysses Guimarães. A coletânea reflete o trabalho da Casa e nela aponta, com apreço, a produção de Afrânio Zucolotto, Domingos Carvalho da Silva, Mário da Silva Brito e Péricles Eugênio da Silva Ramos. Deste, que foi um grande estudante e subsequentemente um grande erudito e seu amigo, destaca o poema "Propiciação".

Antonio Candido, como tantos que o antecederam e sucederam, participou da atividade literária da Faculdade. Colaborou na revista estudantil O Onze de 
Agosto e para o número 1 de junho de 1941 (ano XXXVIII), de cuja Comissão de Redação participava Péricles Eugênio da Silva Ramos, escreveu "Notinha sobre Mário de Andrade". Este artigo coincide no tempo com o seu primeiro comentário sobre livros no número inaugural de Clima (maio de 1941) e provavelmente o antecede na redação. Neste sentido pode-se dizer que o início da atividade de Antonio Candido como crítico literário também está vinculado à Faculdade de Direito. Nesta "Notinha" considerou o poema de Mário, "Louvação da tarde", "um dos cimos de sua obra" e pontuava que o poeta "numa singeleza de atitude e numa singeleza de língua" mostrou que não precisava "revolucionar céus e terras para criar grande poesia". Muitos anos mais tarde, em O discurso e a cidade, o crítico maduro, em abrangente análise, confirmou a sua intuição de jovem. No ensaio "O poeta itinerante" realça a importância do poema e explica como em "Louvação da tarde" Mário de Andrade mostrou que "era capaz de passar do modernismo propriamente dito à modernidade, que recupera a tradição ao superá-la".

Um dos propósitos que presidiu a elaboração de Formação da literatura brasileira, uma das obras fundamentais do percurso de Antonio Candido, foi escrever, no século XX, com domínio da literatura comparada, "uma história dos brasileiros no seu desejo de ter uma literatura". O livro foi construído articulando os momentos decisivos desta história por meio da análise de obras, autores e públicos dos séculos XVIII e XIX. No século XIX, a Faculdade de Direito foi uma decisiva base de sustentação deste desejo dos brasileiros de ter uma literatura. Com efeito, naquela época, nela estudaram e conviveram grande parte dos escritores que, elaborando nas Arcadas a sua visão do país, em seu processo criativo buscaram dar conta da missão de criar uma literatura própria, "procurando uma nova morada" para "o espírito do Ocidente". É por esta razão que, na segunda parte de Formação, dedicada basicamente ao Romantismo brasileiro, são analisadas tantas obras de egressos da Faculdade de Direito, de romancistas como José de Alencar aos poetas tutelares das Arcadas, honrados no Salão Nobre: Álvares de Azevedo, Fagundes Varela e Castro Alves. Na construção "de uma nova morada" para as Letras, o Romantismo, como movimento literário da cultura ocidental, por valorizar os particularismos do "espírito dos povos" prestou-se à estilização das tendências locais. Deste modo conjugaramse as Letras e o instinto de nacionalidade no Brasil do século XIX tendo, nas Arcadas, um grande centro aglutinador e irradiador do propósito da formação de uma literatura brasileira, distinta da matriz lusitana.

Como é sabido, um dos pressupostos de Antonio Candido do processo da formação do sistema literário brasileiro é a interação dinâmica de autores, obras e públicos, com uma certa continuidade da tradição. Isto foi levando a um adensamento de referência mútua, sentido como uma participação na tarefa da construção cultural do país, como realça Roberto Schwarz na sua colaboração para o livro Antonio Candido - pensamento e militância. Por isso, além de obras e autores, estudou os seus públicos. Observo que, da especificidade literária e 
sociológica da relação Escritor/Público, tratou em ensaio que integra Literatura e sociedade. Nele aponta que "o autor só adquire plena consciência da obra quando ela é mostrada através da reação de terceiros. Isto quer dizer que o público é condição do autor conhecer a si próprio, pois esta revelação da obra é a sua revelação". Na análise desta revelação, dada pelo público, deu o devido destaque às consequências literárias do convívio acadêmico.

Neste sentido cabe destacar o já mencionado ensaio "A literatura na evolução de uma comunidade" que também faz parte de Literatura e Sociedade e cujo período de elaboração é o da época em que escreveu Formação. No ensaio mostra como os estudantes da Faculdade, num certo momento do século XIX, formaram a sua sociabilidade específica, criaram um grupo que se justapôs à então modesta e provinciana cidade de São Paulo e, com o seu ethos próprio, configuraram um gosto que marcou o Romantismo brasileiro. Emanaram essencialmente da Faculdade, no âmbito do Romantismo, os traços da melancolia, do satanismo e da atração pela morte.

Estes traços do contexto, interiorizados esteticamente, caracterizam paradigmaticamente a obra de Álvares de Azevedo. À análise destes traços dedicouse posteriormente no estudo sobre Macário e Noite na taverna - narrativas em prosa do menino prodígio - em A educação pela noite, título do ensaio que deu nome ao seu livro, publicado originalmente em 1987. Álvares de Azevedo, o poeta cujo retrato gostava de apreciar como estudante na frequentação da Biblioteca da Faculdade de Direito, é por ele tido "como talvez o mais interessante do nosso romantismo" e a sua obra exprime uma revolta em relação aos valores convencionais. É, assim, representativa da dialética da ordem e da desordem que apontei como um dos seus temas recorrentes. Integra, na sua obra, a importância do topos de "Educação pela noite", realçado por João Luiz Lafetá na sua colaboração para Dentro do texto, dentro da vida, e é um contraponto ao tema das "luzes" da Ilustração, que permeia a primeira parte de Formação da literatura brasileira.

Também é um fruto da convivência acadêmica dos alunos da Faculdade a poesia do bestialógico pantagruélico. A grande figura desta poesia é Bernardo Guimarães, colega e companheiro de Álvares de Azevedo. A esta poesia, que pode ser vista como manifestação de negatividade, que contraria tanto a ordem quanto a finalidade do discurso, Antonio Candido dedicou um instigante ensaio de O discurso e a cidade. São traços do espaço poético criado pela poesia pantagruélica, a graça do absurdo, o cômico, o sadismo, a obscuridade e o tema da brincadeira de que são exemplos "A orgia dos duendes", "A origem do mênstruo" e "O elixir do pajé". Esta poesia é uma expressão do Romantismo paulistano que exprime a sociabilidade especial dos alunos da Faculdade na provinciana vida de São Paulo que se libertavam das convenções por atitudes de negação. É assim, também, uma expressão da recorrente dialética "do a favor" e "do contra" identificadora das inquietações que permeiam a obra de Antonio Candido. 
No livro de amadurecida síntese expositiva, O Romantismo no Brasil, Antonio Candido retoma suas considerações sobre a poesia do Romantismo paulista, fruto do meio da Faculdade de Direito no século XIX, discutindo, com suas especificidades próprias, o elo que vai de Álvares de Azevedo a Bernardo Guimarães e seus companheiros de produção poética.

Uma outra vertente da ligação de Antonio Candido com a Faculdade tem a sua origem no seu interesse pela literatura dos viajantes do século XIX. Na já mencionada entrevista a Heloísa Pontes, conta que, com pouco menos de 14 anos, por sugestão do seu pai, uma das suas iniciações ao conhecimento do Brasil foi a leitura de A segunda viagem ao Rio de Janeiro e à província de Minas Geraes de Saint-Hilaire. Os viajantes ofereceram a Antonio Candido muito material para a reconstituição histórica da vida caipira tradicional na primeira parte de Os parceiros do Rio Bonito - na origem a sua tese de doutorado em Ciências Sociais. Foi a importância do conhecimento do país que as viagens pelo Brasil fornecem que o instigou a organizar, apresentar e anotar em edição de 1995, os Apontamentos de viagem (de São Paulo à capital de Goiás, desta à do Pará pelos rios Araguaia e Tocantins e do Pará à Corte) de J. A. Leite Moraes, originalmente publicado em 1883 e muito representativo dos melhores livros de viagem da época.

Leite Moraes, explica Antonio Candido na introdução, "representa bem as gerações românticas da Faculdade de Direito de São Paulo, das quais tem muitas marcas". Nela ingressou em 1853 e, como era da praxe do convívio acadêmico, participou da vida literária das Arcadas. Foi um aluno aplicado numa turma integrada por Lafaiete Rodrigues Pereira, que veio a ser um dos grandes juristas brasileiros. Tornou-se um advogado criminalista, político e jornalista de fama. Foi lente catedrático de Direito Penal e deixou marcas no folclore acadêmico, inclusive a sua tirada sobre a correlação entre delito e pena: "Na quadrilha do direito o crime dança de vis a vis com a pena". O livro, anotado por Antonio Candido com o seu conhecimento do Brasil, é a consequência da nomeação de Leite Moraes para Presidente da Província de Goiás em 1881. É uma narrativa da sua viagem de ida a Goiás e da volta de Goiás por Belém do Pará e de Belém do Pará para São Paulo. Caracteriza-se pelo sentimento penetrante da natureza e pela capacidade de registrar, de maneira expressiva, fatos e costumes apreendidos por uma pessoa, "muito interessado em averiguar tudo, inclusive para poder orientar o progresso, grande miragem dos homens cultos naquele Brasil atrasado e desconhecido".

$\mathrm{Na}$ Introdução Antonio Candido traça o perfil do prof. Leite Moraes que é, assim, uma importante contribuição às memórias acadêmicas da Faculdade de Direito de São Paulo. Além do interesse próprio do livro e desta contribuição à História da Faculdade, que Antonio Candido conhece bem pela leitura de Almeida Nogueira e Spencer Vampré, seus grandes cronistas - muito utilizado nos estudos acima mencionados sobre o romantismo paulista, vale a pena lembrar outro ponto de contato. Leite Moraes é o avô de 
Mário de Andrade, por quem Antonio Candido sempre teve a maior admiração, manifestada inauguralmente na sua contribuição de 1941 à Revista $O$ Onze de Agosto.

$\mathrm{V}$

No percurso de Antonio Candido um ponto alto da sua convergência com a Faculdade é o texto "O direito à literatura", na sua origem palestra dada num curso organizado em 1988 pela meritória Comissão de Justiça e Paz de São Paulo, da qual fez parte. A palestra, como outras do ciclo, foi proferida na Sala dos Estudantes da Faculdade e posteriormente integrou volume sobre várias facetas dos Direitos Humanos, organizado por A. C. Ribeiro Fester. Subsequentemente, "O direito à literatura" foi incorporado em Vários escritos a partir de sua terceira edição. O texto tem como característica uma conjugação muito própria do Direito e da Literatura. Neste sentido, até simbolicamente por ter sido uma conferência pronunciada na Faculdade, é um compromisso que o antigo aluno, bacharel honorário do XI de Agosto e subscritor da Carta aos brasileiros, saldou com a sua formação jurídica, integrando-a com a sua concepção de literatura e a sua visão da política.

A afirmação histórica dos direitos humanos, que se inicia no século XVIII com as primeiras Declarações de Direitos, representou uma nova concepção da convivência coletiva. Assinalou a positivação jurídica do valor da dignidade humana. Articulou a passagem, no plano do Direito, do dever dos súditos para os direitos do cidadão, como aponta Bobbio em A Era dos Direitos. Inaugurou, na teoria política, o início da consolidação democrática da perspectiva ex parte populi, delimitadora da perspectiva ex parte principis. Tem como ponto de partida as aspirações da tradição humanista das luzes da Ilustração segundo "a qual o homem é um ser capaz de aperfeiçoamento e que a sociedade pode e deve definir metas para melhorar as condições sociais e econômicas" - para recorrer às palavras de Antonio Candido no discurso proferido na Faculdade ao receber, em 2008, o Prêmio Juca Pato. Em síntese, como diz em "O direito à literatura", os direitos humanos nutrem-se das ideias amadurecidas nos séculos XVIII e XIX que geraram o liberalismo e o socialismo e das possibilidades que as conquistas do progresso técnico trariam para encaminhar a solução das grandes desarmonias que geram a injustiça.

Existe, como é sabido, um descompasso entre aquilo que almejam os direitos humanos e a prática, mas cabe, como diz Antonio Candido, aos que neles acreditam empenhar-se em fazer coincidir a teoria com a realidade. No seu caso, o empenho em prol desta coincidência é a expressão de um dever moral - dever que explica tanto a sua militância partidária quanto a não-partidária. É fruto da dimensão do seu "ser socialista", à maneira de D. Teresina, na qual o valor da igualdade flui "de dentro para fora", a partir daquilo que constitui uma espécie de "cerne ético", como analisa Walnice Nogueira Galvão em ensaio que integra o seu Tapete afegão. 
Para a luta em prol da afirmação dos Direitos Humanos vem contribuindo, aponta Antonio Candido, uma mudança de mentalidade, "um progresso no sentimento do próximo" que fez com que o mal, ainda que praticado, tenha deixado de ser proclamado, ou seja, tenha deixado de ser tido como parte integrante e inevitável da natureza das coisas. Exemplifica o sinal dos tempos novos em relação ao mal radical da barbárie nazista com o Tribunal de Nuremberg. Numa outra chave, aponta mudanças no comportamento cotidiano e na fraseologia das classes dominantes no Brasil em relação ao pobre e ao negro.

A discussão da mudança de mentalidade como uma das fontes materiais, favorecedora da positivação jurídica dos Direitos Humanos, é elaborada de maneira muito própria pelo estudioso de literatura. Com a sensibilidade do seu "ser socialista", realça Antonio Candido que, a partir do século XIX, "o pobre entra de vez na literatura como tema importante". Daí a exemplaridade de Os miseráveis de Victor Hugo e o Oliver Twist de Charles Dickens. Explica, assim, que "o que hoje chamamos de direitos humanos pode dar à literatura uma força insuspeitada". Neste contexto pontua o significado de vários livros de Émile Zola, da série dos Rougon-Macquart e no Brasil, pós-Revolução de 1930, o romance de tonalidade social, explícito com Jorge Amado e implícito com Graciliano Ramos. O pano de fundo destas amplas considerações de Antonio Candido está lastreado nos estudos que, como crítico, dedicou, por exemplo, a L'assommoir de Zola (Degradação do espaço) e ao O cortiço de Aluísio de Azevedo (De cortiço a cortiço) incorporados no O discurso e a cidade, a Graciliano Ramos em Ficção e confissão e a Jorge Amado em Brigada ligeira.

O ponto de partida da afirmação dos Direitos Humanos é a generalização do princípio da igualdade e o seu corolário lógico, o princípio da não discriminação. Em termos próprios e muito precisos, em função do "cerne ético" acima mencionado, Antonio Candido formula o que significa a generalização destes dois princípios e as suas dificuldades. Trata-se de "reconhecer que aquilo que consideramos indispensável para nós é também indispensável para o próximo", o que não é fácil, inclusive no plano individual, pois "a tendência mais forte é achar que os nossos direitos são mais urgentes que os do próximo".

Fundamenta a razão de ser da tutela dos direitos humanos no conceito que evocou em Os parceiros do rio Bonito de "bens incompressíveis" do padre Lebret, ou seja, os que não podem nem devem ser negados a ninguém. Neles inclui "não apenas os que asseguram sobrevivência física em níveis decentes, mas os que garantem a integridade espiritual" e afirma: "São incompressíveis certamente a alimentação, a moradia, o vestuário, a instrução, a saúde, a liberdade individual, o amparo da justiça pública, a resistência à opressão, etc.; e também o direito à crença, à opinião, ao lazer". Postula, assim, a interdependência e a indivisibilidade entre os direitos civis e políticos - herança do liberalismo - e os direitos econômico-sociais-culturais - herança do socialismo, contemplados de maneira integrada na Declaração Universal dos Direitos Humanos de 1948. 
Propõe, a seguir, a questão básica do seu texto: a fruição da arte e da literatura é um bem incompressível?

Inicia a discussão apontando que a literatura concebida num sentido amplo, como toda criação de toque poético, ficcional ou dramático, aparece claramente "como manifestação universal de todos os homens em todos os tempos". Com efeito, são múltiplos e diversificados em todos os tipos de cultura os estímulos à criação literária, por ele examinados em ensaio de Literatura e Sociedade. Derivam do fato de que não há povo ou homem que possa viver "sem a possibilidade de entrar em contato com alguma espécie de fabulação" que corresponde, assim, "a uma necessidade universal que precisa ser satisfeita e cuja satisfação constitui um direito". Daí a fundamentação da especificidade do direito à literatura, no sentido amplo, que inclui a cultura popular, no rol dos direitos humanos.

Antonio Candido elabora a fundamentação do direito à fruição generalizada da criação ficcional e artística como um bem incompressível por ser uma necessidade básica, apontando: "Assim como não é possível haver equilíbrio psíquico sem o sonho durante o sono, talvez não haja equilíbrio social sem literatura". A literatura, como "o sonho acordado das civilizações" é um fator indispensável de humanização e "confirma o homem na sua humanidade". Confirma "porque pelo fato de dar forma aos sentimentos e à visão do mundo ela nos organiza, nos liberta do caos e, portanto, nos humaniza". Daí, na perspectiva ex parte populi que os direitos humanos consagram, a titularidade de um direito de crédito ao generalizado acesso de todos aos diferentes níveis de cultura, sem distinção entre cultura popular e cultura erudita. É deste modo que Antonio Candido explicita com originalidade a razão de ser do direito de toda pessoa participar livremente da vida cultural da comunidade e de fruir as artes, consagrado no artigo XXVII - I da Declaração Universal dos Direitos Humanos de 1948 .

$\mathrm{Na}$ discussão do direito à literatura como um igualitário direito de crédito, nos termos acima mencionados, Antonio Candido aprofunda a sua reflexão explicando o seu papel na formação do ser humano. Este papel não é apenas o de divertir, edificar e instruir segundo os clássicos critérios externos que justificariam a literatura segundo padrões oficiais, religiosos ou ideológicos. "A literatura é uma atividade sem sossego" como aponta num ensaio (Timidez do romance) inserido em A educação pela noite, no qual trata da justificação do romance analisando livro de Facan de 1625 - provavelmente o primeiro tratado sobre o romance em prosa - sublinhando, na conclusão, que "o romance representa o desejo de efabulação, com a sua própria verdade".

A literatura, como "uma atividade sem sossego", confirma e nega, propõe e denuncia; "não corrompe nem edifica", mas, trazendo livremente em si o que chamamos o bem e o que chamamos o mal, "humaniza em sentido profundo, porque faz viver". É o caso, por exemplo, do já referido espaço poético criado pela poesia pantagruélica dos alunos da Faculdade. Daí o significado tanto da 
literatura sancionada, quanto da proscrita, que abrem a nossa compreensão para a natureza, a sociedade e o semelhante. É a "poderosa força indiscriminada da iniciação à vida" da literatura, fruto da liberdade "tanto do criador, no momento de conceber e executar, quanto do receptor, no momento de sentir e apreciar", para recorrer ao que diz no ensaio "Estímulos à criação literária" de Literatura e sociedade, que fundamenta o seu papel na formação do ser humano.

Desta análise do direito à literatura e do seu papel na formação do ser humano resulta uma dimensão de liberdade sustentada por Antonio Candido: a da liberdade como Bildung, que enseja o desabrochar do potencial humano através da autônoma construção e amadurecimento da personalidade de cada indivíduo. Esta construção transita pelo "sancionado" e pelo "proscrito" em consonância com o significado da dialética da ordem e da desordem, do "a favor" e do "contra" no percurso da sua obra e das suas inquietações. Daí a contribuição própria de Antonio Candido à fundamentação do direito à livre manifestação e circulação da criação artística contemplado no artigo $5^{\circ}$, IX da Constituição de 1988. Neste sentido, ao sustentar o direito à literatura como um bem incompressível e à maneira do que propõe Bobbio em Política e cultura, advoga uma política de cultura, ou seja, uma defesa dos homens de cultura em prol das condições da existência e desenvolvimento da cultura. Contrapõe-se, assim, à planificação da cultura por critérios externos à literatura, de que são exemplos, como aponta no já referido ensaio "Timidez do romance", as exigências políticas do realismo socialista, nos anos do stalinismo, ou as da aplicação das normas da religião ou da moral dominante, voltadas para inculcar princípios e conhecimentos aceitos pela ordem vigente, que desconsideram ex parte principis a verdade da literatura que nem corrompe nem edifica, em função das suas características próprias.

Com efeito, a verdade da literatura não está na intenção do autor. A intenção pode ser um estímulo à criação literária, mas a verdade própria da literatura é o texto, não o contexto de intenções e estímulos que estão na sua origem. O impacto, por exemplo, da obra de Castro Alves na luta contra a escravidão, explica Antonio Candido, resultou da sua capacidade e do seu talento "de elaborar em termos esteticamente válidos os pontos de vista humanitários e políticos". Desta elaboração tratou num estudo de Recortes sobre "O navio negreiro", poema de 1868, composto em São Paulo pelo acadêmico de Direito Castro Alves. Por isso afirma: "em literatura uma mensagem ética, política, religiosa ou mais geralmente social, só tem eficiência quando for reduzida a estrutura literária, a forma ordenadora".

O poder humanizador da literatura, que enseja a liberdade como "Bildung", resulta da obra como um objeto construído, fruto da "força da palavra organizada". Assim, "um poema hermético, de entendimento difícil, sem nenhuma alusão tangível à realidade do mundo ou do espírito" pode desempenhar este papel humanizador, "pelo fato de ser um tipo de ordem, sugerindo um modelo de superação do caos". Neste sentido, a experiência literária bem sucedida dá 
uma ordem à desordem. Dela é um exemplo a obra de Álvares de Azevedo, para voltar à poesia do romantismo que emanou da Faculdade.

A ordem na literatura, no entanto, tem uma característica especial: a de ser constitutivamente pluralista. Cada texto tem a sua própria, específica e singular maneira de exprimir e organizar a emoção e a visão do mundo dos indivíduos e dos grupos. O artista serve à sua arte cuidando, com autônoma liberdade, desta organização - desta ordem singular - que supera o desordenado caos originário do material bruto com o qual trabalha. Neste sentido, "O direito à literatura" sustenta tanto a liberdade como o não-impedimento, ou seja, a tutela legal da permissão de criar, quanto a liberdade positiva da autonomia, vale dizer, dar à liberdade da criação artística espaço para reger-se pelas suas próprias normas. A base de sustentação destas duas liberdades provém de uma concepção pluralista da cultura que se contrapõe ao monismo da concentração e unificação do poder ideológico, que é o que se exerce sobre as mentes, por meio da palavra, através da produção e transmissão de ideias. A afirmação do pluralismo cultural em contraposição ao monismo em "O direito à literatura" é uma contribuição à teoria democrática.

O pluralismo da verdade da literatura afirmada em "O direito à literatura" tem o seu lastro na postura de Antonio Candido como crítico literário, da qual é expressão o que qualifica como "crítica de vertentes". Esta é a que procura ajustar o tratamento crítico "às características da escrita, não apenas quanto à espécie (poema pessoal, romance social, síntese do período, etc.), mas também quanto à fatura", para usar suas palavras no prefácio de 2003 à edição portuguesa de 2004 de uma coletânea de seus textos ( $O$ direito à literatura e outros ensaios). Requerem abordagens distintas textos translúcidos, que parecem reproduzir a realidade, como os romances realistas de Zola e Aluísio de Azevedo, e textos opacos, que parecem produzir uma realidade própria, como o poema "À espera dos bárbaros" de Kavafis ou o romance de Buzzati, "O deserto dos tártaros". É o que mostram os estudos que integram $O$ discurso e a cidade.

A prática de uma crítica de vertentes que obedece à inclinação de cada texto é a que vem ensejando, na obra de Antonio Candido, o deslinde reflexivo que extrai criativamente do particular de uma obra o seu significado geral, situando-a no saldo das aquisições humanas. É deste modo que, criativamente, ajuda os seus leitores a participarem "por conta própria da extraordinária aventura da liberdade que é a literatura", para valer-me de palavras suas no mencionado prefácio à edição portuguesa de $O$ direito à literatura e outros ensaios.

A crítica de vertentes requer tolerância intelectual. Desta maneira, a sua concepção e prática em termos de direitos humanos, tal como articulada por Antonio Candido, respalda o artigo XXVI da Declaração Universal que, ao prever o direito à instrução, estipula que deverá ser orientada no sentido do pleno desenvolvimento da personalidade humana e promoverá a compreensão e a tolerância. 


\section{VI}

Antonio Candido reiterou, no correr dos tempos, o seu apego pela Faculdade. Nesta minha colaboração procurei explicitar as razões deste apego - afetivas e intelectuais - que explicam o significado da Faculdade no seu percurso e na sua obra. Segui a linha sugerida por Hume, ao tratar da memória, indicando como a interação de causa e efeito de diferentes percepções contribui para entender a sua identidade pessoal e intelectual. Cabe, no fecho deste trabalho, como professor titular da Casa, dizer que a Faculdade também tem apego pelo seu antigo aluno, que exemplificarei com três manifestações institucionais.

A primeira foi na votação do Conselho Universitário, na sua sessão 210, de 9/8/1945 que, funcionando como Congregação da Faculdade de Filosofia, Ciências e Letras, desempatou, em favor de Mário de Souza Lima (que era o regente interino) e em detrimento de Antonio Candido, o concurso para o provimento da Cadeira de Literatura Brasileira para o qual se inscreveram seis candidatos. Num ensaio de Recortes, Antonio Candido relata as peripécias deste concurso, que disputou aos 26 anos, e que acabou por dar-lhe, com a tese sobre o método crítico de Sílvio Romero, o título de livre-docente da literatura brasileira que foi, mais adiante, o passaporte de titulação da sua passagem do ensino da Sociologia para o de Letras. Obteve cinco indicações da Banca, mas dois também indicaram Souza Lima e um Oswald de Andrade. Subsequentemente, os três examinadores que haviam votado nele e também nos dois acima mencionados, desempataram em seu detrimento, ficando, assim, Souza Lima com duas indicações, Oswald com uma e ele com duas. No Conselho Universitário Antonio Candido teve cinco votos minoritários respaldando a sua indicação. Um deles foi o de Ernesto de Moraes Leme - que tinha sido seu professor de Direito Comercial, que o apreciava como crítico e com o qual manteve, no correr dos tempos, um bom relacionamento.

A penúltima manifestação foi a que lhe foi prestada no Salão Nobre pela Diretoria da Faculdade e pela Associação dos Antigos Alunos, em 2005. Foi distinguido, entre os antigos alunos, por suas destacadas atividades fora do segmento jurídico, como o crítico literário mais considerado do país, como relata Folha dobrada, o informativo da Associação dos Antigos Alunos da Faculdade de Direito da Universidade de São Paulo (ano 4, no 17, setembro de 2005).

A última foi em 20 de agosto de 2008, por ocasião da entrega do prêmio Juca Pato, quando recebeu, de Lygia Fagundes Telles, a láurea de Associado Benemérito da Associação de Antigos Alunos e do diretor da Faculdade, João Grandino Rodas, o diploma do Colar do Mérito Acadêmico das Arcadas da São Francisco. O Colar do Mérito Acadêmico, criado em junho de 2007, no contexto do aniversário dos 180 anos da Faculdade, foi concedido pela primeira vez, por deliberação unânime da Congregação, a Antonio Candido como também relata Folha dobrada, o informativo da Associação dos Antigos Alunos da Faculdade de Direito da USP (ano VII - no 9, julho/setembro 2008). Os consideran- 
dos que levaram à deliberação da Congregação sintetizam os argumentos deste texto, que são indicativos do reconhecimento dos relevantes serviços que a sua obra e ação prestaram à Faculdade, ampliando o entendimento do seu papel como um local de memória na vida brasileira.

Permito-me concluir com uma nota pessoal. No curso em que fui seu aluno sobre Teoria e Análise do Romance foram discutidos vários tipos de personagens, desde as mais próximas do tipo até as mais complexas. No ensaio "A personagem do romance", que integra A personagem de fiçção - livro que reúne as colaborações de expositores convidados do curso - observa Antonio Candido que a marcha do romance moderno tem como uma das suas notas tratar as personagens como "seres complicados, que não se esgotam nos traços característicos, mas têm certos poços profundos, de onde pode jorrar a cada instante o desconhecido e o mistério". Este tema do curso é uma das facetas da sua obra de crítico, voltada para a análise da complexidade contraditória de personagens que, com seus altos e baixos, integram o universo ficcional de vários escritores. Este problema, difundido pelo Romantismo, é o fio condutor dos ensaios sobre Alexandre Dumas, Joseph Conrad, Graciliano Ramos, Guimarães Rosa, que integram Tese e antítese que li assim que foi publicado em 1964, na sequência das inquietações intelectuais suscitadas pelo curso.

No correr dos anos e também subsequentemente com um saber de experiência, fui me dando conta da relevância disso para o entendimento da vida política. Com efeito, como adverte Octavio Paz no prólogo a La letra y el cetro, o volume 9 de suas obras completas, ninguém deveria escrever sobre temas de filosofia e teoria política sem ter lido e meditado sobre o legado dos grandes poetas e romancistas - os trágicos gregos, Shakespeare, Dante, Cervantes, Balzac, Dostoievski. A História e a Política, continua ele, são os domínios da eleição do particular e do único, da paixão, dos conflitos, dos amores, dos ódios, dos ciúmes, da admiração, ou seja, de tudo de bom e de tudo de mau que faz parte do ser humano. Por isso, na política sempre ocorre, tanto no mando quanto no desmando, o enlace entre as forças impessoais dos processos sócio-históricos e o bom e o mau das paixões humanas.

A literatura nos dá acesso ao entendimento desta complexidade, como mostra Antonio Candido na sua análise do mando e da transgressão no Ricardo II de Shakespeare, ensaio de 1992 que integrou o volume coletivo Ética, organizado por Adauto Novaes.

Hannah Arendt, na sua reflexão, frequentemente recorreu à literatura como via de acesso ao entendimento da realidade política. Quando fui seu aluno, em 1965, em Cornell, no curso sobre As Experiências Políticas no Século XX, uma parte significativa da bibliografia indicada era ficção. Incluía romances de Ernst Jünger, William Faulkner, André Malraux, Ernest Hemingway, Jean-Paul Sartre, Thomas Mann, Boris Pasternak e poesias de Brecht e René Char.

O acesso ao contraditório pluralismo do bom e do mau, do "a favor" e o "do contra", da ordem e da desordem, foi o que, na minha formação, logrei perce- 
ber no homo fictus do curso sobre Teoria e Análise do Romance. Foi a base para começar a entender o quanto de "os crespos do homem" existe nos seres vivos. Por isso sou um antigo e sempre aluno de Antonio Candido, não só de Teoria Literária e Literatura Comparada, mas de vida. 